\title{
THE \&FFECTS OF THE GLOBAL FINANCIAL CRISIS ON TOP 40 COMPANY CFOS
}

\author{
Thea L Voogt* \\ University of Johannesburg \\ tlvoogt@uj.ac.za
}

July 2011

\begin{abstract}
Very little country-specific information is available on the effects of the global financial crisis on developing countries. This article focuses on the effects of the global financial crisis on the chief financial officers (CFOs) of the 40 largest listed companies on the JSE Ltd and achieves four objectives. Firstly, it provides perspectives on the effects of the global financial crisis on South Africa. Secondly, it details a literature review on the effects of the crisis on CFOs globally. Thereafter, a model is presented of the roles and responsibilities of CFOs, which, together with the literature review and previous similar research, was used as the basis for a questionnaire. Lastly, this article reports on the responses to the questionnaire. The research revealed eight significant findings and a number of specific areas for research. Among these significant findings were that respondents' perceptions of an increase in importance in some of their roles did not correspond to the time they spend and expect to spend on responsibilities related these roles. In addition, respondents expected to spend even less time on IT and sustainability. This article provides valuable insights into the extent of the effects of the global financial crisis on CFOs.
\end{abstract}

\section{Keywords}

Chief financial officer, Compliance and transaction officer, Corporate governance, citizenship and people manager, Evolving role, Global financial crisis, Growth and innovation catalyst, IT responsibilities, Largest listed companies, Planner and strategist, Strategic planning, Sustainability issues

* Prof Thea Voogt is professor in the Accountancy Department at the University of Johannesburg, South Africa. 


\section{INTRODUCTION}

The global financial crisis, which had its greatest impact in 2007/2008, has had an enormous impact, with stock markets falling, financial institutions collapsing and governments forced to intervene with bailouts, while refocusing on regulatory reform (Aronson, 2010; Germain, 2009; Legg \& Harris, 2009; 0'Driscoll, 2009; Overseas Development Institute [ODI], 2008). Though there was some respite towards the end of 2009 and the beginning of 2010, the second quarter of 2010 has been characterised by more economic turmoil, with looming sovereign debt crises in Europe, high deficit levels, pressure on the stability of the Euro-zone, stock markets falling across the globe and fears that a double dip recession may materialise (Censky, 2010; Germain, 2009; Roubini, 2010; Shiller, 2010).

Even though countries in Africa have not suffered the same banking crisis that many other parts of the world have, the continent has not come through the global financial crisis unscathed (Ali, 2009; Arieff, Weiss \& Jones, 2010; International Monetary Fund [IMF], 2009; Macias \& Massa, 2009; ODI, 2008; ODI, 2009). Some evidence has emerged as to the wider effects of the global financial crisis on developing countries, but country-specific research on the economic, social and political consequences of the financial crisis is urgently needed (ODI, 2008; Te Velde, 2008).

Briefly, this article focuses on the effects of the global financial crisis on the chief financial officers (CFOs) of the largest listed companies on the JSE Ltd in South Africa.

\section{PROBLEM STATEMENT, PURPOSE AND OBJECTIVES}

The debate on how CFOs, and for that matter all finance professionals, should prepare and position themselves for the future in an ever-changing environment has been ongoing. To this end, the South African Institute of Chartered Accountants (SAICA) performed research in 2008 on the roles and responsibilities of the CFOs of the 40 largest listed companies on the JSE Ltd (SAICA, 2008). However, that research was conducted and published prior to the global financial crisis. Hence, in 2010, SAICA requested that follow-up research be conducted, again focusing on the roles and responsibilities of CFOs and a number of related matters, in order to determine the extent, if any, of the effects of the global financial crisis on them.

The purpose of this article is to report on the results of this research. In doing so, it will achieve four objectives. Firstly, some perspectives will be provided on the effects of the global financial crisis on South Africa, as the CFOs who were surveyed were all employed by companies listed on the JSE Ltd, situated in South Africa. Secondly, even though a thorough search of peer-reviewed articles on the effects of the global financial crisis on CFOs revealed very little, this article will nevertheless report on the matter using other sources. In doing so, it will present international perspectives on the changing roles and responsibilities of CFOs following the global financial crisis. Thirdly, the model that was used in 2008 as the basis for research conducted on SAICA's behalf into the roles and responsibilities of CFOs in the South African context will be presented. This model, together with the literature review, and results stemming from the 2008 research (SAICA, 2008; Voogt, 2010), was used as the basis for a questionnaire, which was compiled as an exploratory and comparative research tool in 2010. Lastly, this article will report on the responses to the questionnaire, and will present significant findings and come to some conclusions about the effects of the global financial crisis on the CFOs of the largest listed companies on the JSE Ltd. 
The research informing this article provides significant and valuable country-specific insights into the consequences of the global financial crisis on CFOs and makes a valuable contribution to the understanding of the roles and responsibilities of CFOs following the crisis.

\section{LIMITATIONS OF THE STUDY}

Even though this article presents valuable research, which allows for comparisons between the roles and responsibilities of the CFOs before and after the global financial crisis, one should bear in mind that it does not present the views of all CFOs, because it focused on the views of CFOs at the Top 40 JSE Ltd listed companies. Hence, conclusions drawn in this study may not reflect the views of all the CFOs of companies listed on the JSE Ltd.

\section{SOME PERSPECTIVES ON SOUTH AFRICA AND THE GLOBAL FINANCIAL CRISIS}

In 2008, the ODI predicted that as a developing country highly dependent on foreign direct investment, South Africa would be hard pressed to reduce interest rates during the global financial crisis, a position further exacerbated by a high current account deficit and pressure on its exchange rate and inflation rate (te Velde, 2008). The possible negative effects on South Africa were also echoed in 2009, when the World Bank classified South Africa as having a high exposure to the global financial crisis (ODI, 2009). The IMF concurred in 2009, when it listed South Africa with Nigeria, Ghana and Kenya as the African countries first to be hit by the crisis. In addition, the IMF pointed out that South Africa and Nigeria could be particularly hard hit when it came to external financing for corporations and banks, which was becoming scarce (IMF, 2009). As could be expected, in 2009 the South Africa market was affected by a large drop in share prices (Macias \& Massa, 2009).

The South African government's response was set out in the 2009 Framework for South Africa's response to the international economic crisis. Within the Framework, the broad principles of the government's response were to (South African Government Information, 2009a:4-5):

- Put measures in place to protect low-income earners, the unemployed and vulnerable groups;

- Strengthen the capacity of the economy to grow and create decent jobs;

- Maintain high levels of public sector infrastructure investment and encourage private sector investment and corporate social investment programmes;

- Put an economic and social stimulus package in place.

Even though the efficacy of this response is debatable, for the most part, South Africa escaped the banking crisis (Bruggemans, 2007/2008; Paton, 2010). Economic data revealed that South Africa largely escaped the recession in the third and fourth quarters of 2009 (South African Reserve Bank, 2010), showed growth in real gross domestic product (South African Reserve Bank, 2010), and confidence in the financial sector also increased (South African Reserve Bank, 2010).

But the country has not been left unscathed (Kana, 2009). For example, there was a sharp decline in demand for export products and a fall in commodity prices, with global fund managers and portfolio investors somewhat wary of investments in emerging markets such as South Africa 
(South African Government Information, 2009b). As regards job losses, in his 2010 state of the nation address, President Jacob Zuma stated that the result of the recent global financial crisis was that approximately 900000 jobs were lost in SA in 2009 (Zuma, 2010).

Looking at the direct impact of the global financial crisis on business in South Africa, a number of important points can be raised, including (Kana, 2009:20-22):

- There will be continued pressure on companies due to the reduced availability of credit.

- Many companies will find themselves trapped between slower recoveries from debtors and payment pressure from suppliers.

- The global downturn has an effect on impairment calculations.

- Pension fund deficits may become more common.

- Acquisition activities will be on the decrease.

- Boards will need to pay close attention to finding growth opportunities and working out how to grasp them under situations where borrowings and working capital could come under pressure.

It is within this environment that CFOs are facing a range of challenges while their own roles also evolve.

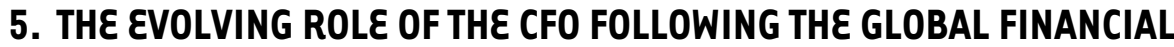 CRISIS}

Many books, journal articles and research reports have been published on the evolving role of the CFO, which has taken him/her from scorekeeper to strategist and business partner (Bragg, 2007; Ernst \& Young, 2008; Financial Executives International, 2005; IBM Business Consulting Services, 2003; Institute of Chartered Accountants in Australia [ICAA], 1998; ICAA, 2007; International Federation of Accountants, 2002; Myers, 2002; SAICA, 2008; Voogt, 2010).

But the global financial crisis has added yet more dimensions to the roles and responsibilities of CFOs, many of which are reflected upon in recent research reports and articles (even though very little on the effects of the global financial crisis on CFOs has been published in peer-reviewed journals).

For example, in 2008, the Financial Times in association with IBM released The CFO in Uncertain Times Summary Report, following a CFO forum. Reflecting on the global financial crisis, the report pointed out that CFOs would need to "adjust targets and plan for tougher times" (Financial Times, 2008:3). On the question of whether CFOs should focus on compliance and simply reducing costs during difficult economic times, forum participants felt that CFOs instead had to focus on looking for opportunities, whether in cost reduction, revenue, assets or staffing (Financial Times, 2008:6).

Turning now to the focus areas of $\mathrm{CFO}$ s, one view was that they had to focus on five issues (Deloitte, 2008): conserving cash and controlling costs, diversifying their sources of capital and establishing new credit lines, securing receivables and supply chains, looking at opportunities to purchase strategic assets and considering a new mix of capital to finance their companies. Much emphasis was also placed on the role that CFOs had to play in securing credit and access to cash together with the importance of their relationship with bankers (Banham, 2009). Other views 
around the effects of the global financial crisis on CFOs included that they felt that risk management was their top priority and that poor risk management was one of the major contributing factors to the crisis (Towers Watson, 2008). But perhaps more disturbing was the view that the rapidly changing preferred skills for CFOs was contributing to the high rate of turnover of CFOs (A.E. Feldman Blog, 2008).

In 2009, Deloitte released two reports reflecting on the challenges that CFOs face amid the global financial crisis. Firstly, in Priorities for 2009: Cash, confidence, costs, CFOs reflected on the most important challenges for them in the constrained economic environment: maximising cash flow and liquidity, improving investor confidence, reducing operating costs and reducing capital spending (Deloitte LLP, 2009a:1, 3). On the whole, the report revealed that a large proportion of CFOs were turning risk averse (Deloitte LLP, 2009a:1, 4). Secondly, in Amid the gloom, glimmers of hope, CFOs' views were that a reduction in debt and in cost were key going forward (Deloitte LLP, 2009b:5).

Turning to IT issues, in the context of the challenges that CFOs face, CFO Research Services released a report in 2009 entitled Road to Recovery: Finance's views on IT investments for efficiency and competitive advantage. The report detailed the results of a survey to which 198 senior finance executives responded on various aspects of IT investments amid the global recession. On the whole, these executives felt that IT continues to play an important role in providing a competitive advantage in their organisations, even in times where IT-related expenditure is being cut (CFO Publishing Corp., 2009). Specifically, 22\% of respondents felt that technology was a key factor in a company's competitive position after the global financial crisis, while $49 \%$ felt it to be somewhat important in that efficient systems could help to improve a company's competitive position (CFO Publishing Corp., 2009). As to whether they felt it was more likely that they would modify existing systems rather than introduce new ones amid the crisis, $71 \%$ felt that they would modify their existing enterprise resource planning (ERP) systems, rather than introduce new ones, while the same percentage of respondents felt that way about IT shared services centres (CFO Publishing Corp., 2009).

CPA Australia added to the debate on how CFOs should show leadership during the economic downturn by providing twelve guiding principles for them to apply. These included (CPA Australia, 2009): developing a spreadsheet financial model for a business around its key operating metrics, reviewing government's responses to the global financial crisis, securing funding options in advance of requiring it, considering options for merger and acquisition activities, in the case of strong companies, and being more aware of their duties as directors.

Responding to the decrease in tenure of CFOs at Fortune 500 companies from five to three years, the Korn/Ferry Institute considered five benefits of long-tenured CFOs and stability in the position of CFO in the global financial crisis (Korn/Ferry Institute, 2010): a deep and trusting relationship between the CFO, chief executive officer (CEO), senior executive, the board of directors, bankers and stakeholders; a broad understanding of their businesses; the uncommon ability to serve as strategic business partner; a steady hand during the crisis; and mastery of detail.

IBM released a comprehensive report entitled The New Value Integrator - Insights from the Global Chief Financial Officer Study, which reflected the views of more than 1900 CFOs (IBM, 2010). It emerged that CFOs lately had "far more influence at the enterprise level" and that CEOs and boards of directors relied even more on CFOs "to be fact-based voices of reason and insight" (IBM, 2010:6). But this does not go without challenges. More than $45 \%$ of respondents 
were of the opinion that their finance functions were not effective in the important areas of strategy, information integration and risk and opportunity management (IBM, 2010:6).

As to the effects of the global financial crisis, the IBM report revealed the following:

- CFOs expect volatility and uncertainty to continue (IBM, 2010:12);

- There will be further pressure on cost reduction, faster decisions and more transparency to external stakeholders over the next three years (IBM, 2010:12);

- More than $70 \%$ of CFOs felt that they were either advising on or playing an integral part in decision making (IBM, 2010:12);

- Two activities that have become more prominent on the CFO agenda were information integration as a source of business insight, and risk management (IBM, 2010:14, 15), both pointing to a further shift in the role of CFOs (IBM, 2010:15).

Interestingly, IBM proposed that there are four finance function profiles (IBM, 2010:21): scorekeepers (data recording, controllership, multiple versions of the "truth"), disciplined operators (finance operations-focused, information provision, performance interpretation), constrained advisors (analytics-focused, sub-optimal execution, fragmented data) and value integrators (performance optimisation, predictive insights, enterprise risk management and business decision making). The report detailed clear evidence that value integrators excel at navigating uncertainty (IBM, 2010:21), information integration and risk management (IBM, 2010:22), finance efficiency and business insight (IBM, 2010:8). But the reality that transaction processing still dominated CFOs' workload across the board was also apparent, even though CFOs continued to aspire to reduce this element of their workload (IBM, 2010:41).

In 2010, KPMG also categorised CFOs and determined that there were six profiles for them and ascribed a percentage to the number of CFOs they thought would fit into each (KPMG, 2010):

- Internal growth leaders, 39\%. These CFOs focus on achieving higher growth and excel as strategists in emerging markets, sales force optimisation and organic diversification;

- Cost-cutters, $23 \%$. CFOs in this category use cost-cutting, outsourcing and downsizing to achieve their goal;

- External growth leaders, 20\%. These CFOs specialise in planning, executing and integrating mergers and acquisitions;

- Business transformers, $12 \%$. CFOs in this category identify and oversee reorganisation plans with a focus on corporate structures and process redesign to increase productivity;

- Finance specialists, $4 \%$. Within this category, CFOs focus on financial planning and execution;

- Risk moderators, $2 \%$. CFOs who are focused on identifying and mitigating risk.

Similarly (but prior to the global financial crisis), Ernst \& Young identified four roles for CFOs (Ernst \& Young, 2008): business partner, commentator, scorekeeper and custodian. For its part, Deloitte categorised the roles as steward, operator, strategist and catalyst (Deloitte Development LLC, 2007).

Another model of the key focus areas of CFOs, which was recently used in South African-based research on CFOs (SAICA, 2008; Voogt, 2010), will be discussed . 


\section{A SOUTH AFRICAN MODEL FOR THE KEY FOCUS AREAS OF CFOS}

In 2008, Voogt developed a model for the key focus areas of CFOs that reflected uniquely South African drivers, paying attention to issues such as the general skills shortage and black economic empowerment (Voogt, 2010). Within the model, there are four key focus areas or roles (planner and strategist, compliance and transaction officer, growth and innovation catalyst, and corporate governance, citizenship and people manager), and a range of responsibilities that CFOs have under each.

This model, which is presented in Table 1, formed the basis of a questionnaire that facilitated research for SAICA into the roles and responsibilities of the CFOs of the 40 largest listed companies in South Africa in 2008 (Voogt, 2010).

Results from the SAICA research gave clarity on the ranking of the four roles for CFOs at these companies at that time and looking ahead five years. At that stage, their single most important role was that of planner and strategist, then came compliance and transaction officer, followed by corporate governance, citizenship and people manager and growth and innovation catalyst. Looking ahead five years, their single most important role remained that of planner and strategist, but the ranking of the remaining roles changed. In second place was their role as growth and innovation catalyst, then compliance and transaction officer and lastly corporate governance, citizenship and people manager (SAICA, 2008; Voogt, 2010). In addition to these results, based on arithmetical means of grouped discrete data, it was found that strategic planning, advice and management was the one responsibility they spent most of their time on then and looking forward five years (Voogt, 2010).

The model depicted in Table 1, the results achieved in 2008 as well as the literature review reported on above formed the basis for a questionnaire administered in 2010 to study the roles and responsibilities of CFOs further, following the global financial crisis.

\section{THE POPULATION, RESPONSE RATE AND BIOGRAPHICAL INFORMATION}

In order to allow for comparisons between the roles and responsibilities of CFOs before and after the global financial crisis, the population selected for the research conducted in 2010 mirrored that used in 2008: the CFOs of the 40 largest listed companies ranked by market capitalisation in the JSE's All-Share Index, referred to as the FTSE/JSE Top 40 Index (Voogt, 2010). Companies in this index represent almost $90 \%$ of the market value of all companies listed on the JSE Ltd and as such would represent the interests of a wide spectrum of stakeholders (Voogt, 2010).

Based on market capitalisation as at 13 January 2010, the CFOs of the companies listed in Table 2 made up the population. 
TABLE 1: A South African model of the key focus areas of CFOs

\begin{tabular}{|c|c|}
\hline PLANNER AND STRATEGIST & GROWTH AND INNOVATION CATALYST \\
\hline $\begin{array}{l}\text { Providing financial leadership through financial } \\
\text { planning and strategies aligned with business } \\
\text { strategies } \\
\text { - Strategic planning, advice and management } \\
\text { - } \quad \text { Strategic alliances } \\
\text { - } \quad \text { Risk identification, assessment and } \\
\text { management } \\
\text { - } \quad \text { Strategically using information for a } \\
\text { - } \quad \text { Competitive edge } \\
\text { - } \quad \text { Program, project and contracts management } \\
\text { - } \quad \text { and evaluation } \\
\text { - } \quad \text { Budgt benefit planning, scenario planning } \\
\text { - } \quad \text { Treasury, tax, human resources, resources and } \\
\text { - } \quad \text { Benital investment planning } \\
\text { - } \quad \text { Technology leverage and information } \\
\text { management and technology strategies } \\
\text { Skills identification and planning }\end{array}$ & $\begin{array}{l}\text { Continuously finding new ways of creating shareholder } \\
\text { value by looking outside of the organisation } \\
\text { - } \quad \text { Transformation } \\
\text { - } \quad \text { Mergers and acquisitions } \\
\text { - } \quad \text { Thought leadership } \\
\text { - } \quad \text { New products and markets } \\
\text { - } \quad \text { New business ventures } \\
\text { - } \quad \text { Creation of shareholder wealth } \\
\text { - } \quad \text { Capital provision and sourcing }\end{array}$ \\
\hline COMPLIANCE AND TRANSACTION OFFICER & $\begin{array}{c}\text { CORPORATE GOVERNANCE, CITIZENSHIP AND } \\
\text { PEOPLE MANAGER }\end{array}$ \\
\hline $\begin{array}{l}\text { Taking responsibility for transactional and financial } \\
\text { reporting, compliance and strategy implementation } \\
\text { - } \quad \text { Information, technology maintenance and } \\
\text { - } \quad \text { Opanagement } \\
\text { - } \quad \text { Compliance and investor regulations } \\
\text { - } \quad \text { Internal controls, assurance, internal audit } \\
\text { - } \quad \text { Busd fraud } \\
\text { - } \quad \text { Management information and forecasting } \\
\text { - } \quad \text { Treasury and cash management } \\
\text { - } \quad \text { Taxation } \\
\text { - Transactional processing and financial } \\
\text { - } \quad \text { IFRS implementation } \\
\text { - Stakeholder financial reporting } \\
\text { - Implementation of risk management strategies }\end{array}$ & $\begin{array}{l}\text { Helping to build corporate governance structures, } \\
\text { taking up responsibilities of the organisation as good } \\
\text { corporate citizen and nurturing relationships inside and } \\
\text { outside the organisation } \\
\text { - } \quad \text { Social transformation and BEદ } \\
\text { - } \quad \text { Sustainable development } \\
\text { - } \quad \text { Sustainability reporting } \\
\text { - } \quad \text { Triple bottom line } \\
\text { - } \quad \text { Investor relationships } \\
\text { - } \quad \text { Stakeholder communication and liaison } \\
\text { - } \quad \text { Attracting and retaining skills } \\
\text { - } \quad \text { Reputation management } \\
\text { - } \quad \text { Coaching and mentoring } \\
\text { - } \quad \text { Lifelong learning and professional development } \\
\text { - } \quad \text { Market confidence } \\
\text { - } \quad \text { Governance structures } \\
\text { - } \quad \text { Ethics and values } \\
\text { - } \quad \text { Ethical reporting } \\
\text { - } \quad \text { Going concern } \\
\text { - } \quad \text { Liaison with the board, audit committee, internal } \\
\quad \text { audit and external audit }\end{array}$ \\
\hline
\end{tabular}

Source: Voogt (2010) 
TABLE 2: Companies included in the population

African Bank Investments Ltd

Anglo American plc

AngloGold Ashanti Ltd

African Rainbow Minerals Ltd

BHP Billiton plc

Compagnie Financière Richemont SA

FirstRand Ltd

Growthpoint Properties Ltd

Impala Platinum Holdings Ltd

Kumba Iron Ore Ltd

Liberty International plc

MTN Group Ltd

Naspers Ltd

Pick n Pay Holdings Ltd

Reinet Investment SCA

RMB Holdings Ltd

Standard Bank Group Ltd

Shoprite Holdings Ltd

Sasol Ltd

Telkom SA Ltd
ArcelorMittal South Africa Ltd

Anglo Platinum Ltd

Aspen Pharmacare Holdings Ltd

ABSA Group Ltd

Bidvest Group Ltd

Exxaro Resources Ltd

Gold Fields Ltd

Harmony Gold Mining Company Ltd

Investec Ltd and Investec plc

Liberty Holdings Ltd

Lonmin plc

Nedbank Group Ltd

Old Mutual plc

Pretoria Portland Cement Company Ltd

Remgro Ltd

SABMiller Plc

Steinhoff International Holdings Ltd

Sanlam Ltd

Tiger Brands Ltd

Vodacom Group Ltd

\section{Source: $\quad$ SAICA, 2010:15}

In order to obtain the widest possible views in the population, which is small, a census was conducted. Therefore, all the CFOs were surveyed, even though the head offices and/or offices of some of the CFOs were not situated in South Africa (as depicted in Table 3).

As Table 4 reflects, the response rate to the questionnaire was high.

\section{TABLE 3: Location of head offices and/or offices of CFOs}

\begin{tabular}{lcc}
\hline & $\begin{array}{c}\text { Number of } \\
\text { companies }\end{array}$ & $\%$ \\
\hline Head office and/or offices of CFO in South Africa & 31 & 77.5 \\
Head office and/or offices of CFO outside of South Africa & 9 & 22.5 \\
Total number of companies in the population & 40 & 100 \\
\hline
\end{tabular}

Source: $\quad$ SAICA, 2010:15 
TABLE 4: Response rate

\begin{tabular}{lcc}
\hline & $\begin{array}{c}\text { \#CFOs } \\
\text { targeted }\end{array}$ & $\%$ \\
\hline $\begin{array}{l}\text { Completed questionnaires received back } \\
\text { Respondents indicated their willingness to participate, but did not complete } \\
\text { the questionnaire due to being overseas for a long period, being new to the } \\
\text { position, or schedules that could ultimately not accommodate the completion } \\
\text { of the questionnaire }\end{array}$ & 26 & 65 \\
No response & 3.5 \\
Total & 11 & 27.5 \\
\hline
\end{tabular}

Source: $\quad$ SAICA, 2010:16

Of the respondents, four (44\%) who were based outside of South Africa completed the questionnaire, while $22(71 \%)$ of the CFOs based in South Africa did so. The respondents represented a range of sectors, including mining, retailing, telecommunication, banking and life assurance, manufacturing, beverages and publishing. Of the 26 respondents, 23 (88\%) were male and three (12\%) female. The age profile of the respondents is set out in Table 5.

TABLE 5: Age profile of respondents

\begin{tabular}{lcc}
\hline & $\begin{array}{c}\text { Number of } \\
\text { respondents }\end{array}$ & $\%$ \\
\hline 35 to 44 years of age & 6 & 23 \\
45 to 54 years of age & 15 & 58 \\
55 to 65 years of age & 5 & 19 \\
Total & 26 & 100 \\
\hline
\end{tabular}

Source: SAICA, 2010:17

With regards to the professional designation of the respondents, the vast majority were chartered accountants, which underscores the importance of the qualification. These findings are also in line with recent SAICA research that revealed that 318 South African chartered accountants serve on the boards of JSE Ltd Top 100 companies (SAICA, 2009).

The professional designation of respondents is set out in Table 6.

TABLE 6: Professional designation of respondents

\begin{tabular}{lcc}
\hline & $\begin{array}{c}\text { Number of } \\
\text { respondents }\end{array}$ & $\%$ \\
\hline CA (SA) & 21 & 81 \\
Chartered accountant from another institute & 3 & 11.5 \\
Not a chartered accountant & 2 & 7.5 \\
Total & 26 & 100 \\
\hline
\end{tabular}

Source: SAICA, 2010:17

Over and above the biographical information obtained and presented above, the questionnaire addressed a number of issues related to the roles and responsibilities of CFOs in the light of the 
global financial crisis. Coding of responses was performed at the time of data capture. Findings are presented.

\section{FINDINGS}

\subsection{Views on whether CFOs felt their role had changed due to the global financial crisis}

One of the first themes in the questionnaire was to determine whether the CFOs of the largest listed companies on the JSE Ltd felt that their role had changed due to the global financial crisis. Results revealed that $16(64 \%)$ respondents felt that it had changed, while nine $(36 \%)$ felt that their role did not change due to the global financial crisis (with one respondent choosing both options, and hence not being included in the statistics).

In order to further probe the extent to which each of their four roles in the model in Table $\mathbf{1}$ had changed due to the global financial crisis, the respondents who indicated that they felt their role had changed were presented with the roles and asked to indicate whether there was a decrease, stability or an increase in focus in each role. The results (see Table 7) reveal that almost all felt that their role as planner and strategist increased in importance due to the global financial crisis. Responses were mixed as to whether the roles of compliance and transaction officer had changed, while, on the whole, respondents tended to favour an increase in the importance of the remaining two roles due to the global financial crisis, particularly their role as growth and innovation catalyst.

When respondents were asked to look ahead and indicate whether they thought their role as CFO would change over the next three years, $17(65 \%)$ respondents felt that their role as CFO would change, as opposed to nine (35\%) who felt their role would not change further over the next three years.

TABLE 7: Effects of the global financial crisis on the four roles of a CFO

\begin{tabular}{|c|c|c|c|}
\hline \# & $\begin{array}{l}\text { Decrease in } \\
\text { focus }\end{array}$ & $\begin{array}{l}\text { Remained } \\
\text { unchanged }\end{array}$ & Increase in focus \\
\hline Planner and strategist & 1 & 1 & 13 \\
\hline Compliance and transaction officer * & 3 & 9 & 4 \\
\hline Growth and innovation catalyst & 2 & 5 & 8 \\
\hline $\begin{array}{l}\text { Corporate governance, citizenship and } \\
\text { people manager }\end{array}$ & 2 & 6 & 7 \\
\hline
\end{tabular}

Source: SAICA, 2010:21

* One respondent selected two options

\# One respondent indicated that he/she felt a change in roles, but did not indicate how each of the four roles had changed

The 17 respondents who indicated that they felt their role would change over the next three years were asked whether there would be a decrease, stability or an increase in focus in each role. The results presented in Table 8 indicate that $71 \%$ of those respondents felt their role as planner and strategist would increase even further, while $76 \%$ expected an increase in focus in their role as growth and innovation catalyst. 
TABLE 8: Expected change in focus in three years' time

\begin{tabular}{lccc}
\hline & $\begin{array}{c}\text { Decrease in } \\
\text { focus }\end{array}$ & $\begin{array}{c}\text { Remained } \\
\text { unchanged }\end{array}$ & Increase in focus \\
\hline Planner and strategist & 0 & 5 & 12 \\
$\begin{array}{l}\text { Compliance and transaction officer } \\
\text { Growth and innovation catalyst }\end{array}$ & 6 & 5 & 6 \\
$\begin{array}{l}\text { Corporate governance, citizenship and } \\
\text { people manager }\end{array}$ & 2 & 8 & 13 \\
\hline
\end{tabular}

Source: SAICA, 2010:21

A comparison of the overall future results in 2008 and 2010 shows that in $200894 \%$ of respondents felt that their role as CFO would change in five years' time (SAICA, 2008), while 2010 results reveal that only $65 \%$ of the $\mathrm{CFO}$ s at the targeted companies felt their role would change in three years' time.

\subsection{Views on the relative importance of each of their roles}

The second important theme researched in 2010 through the application of the questionnaire was to consider the most important role for $\mathrm{CFO}$ s, as well as the relative importance of each role to them. In order to accomplish this goal, respondents were asked to select the one role most important to them now (presented in Table 9) and to indicate the relative importance of each role to them now (presented in Table 10), both in light of the global financial crisis.

\section{TABLE 9: One role most important to respondents now}

\begin{tabular}{lcc}
\hline & $\begin{array}{c}\text { Number of } \\
\text { respondents }\end{array}$ & $\%$ \\
\hline Planner and strategist & $19 \star$ & 70 \\
Compliance and transaction officer & 4 & 15 \\
Growth and innovation catalyst & $2 \star$ & 7.5 \\
Corporate governance, citizenship and people manager & 2 & 7.5 \\
\hline
\end{tabular}

Source: SAICA, 2010:22

* One respondent selected two options 
TABLE 10: Relative importance of roles now

\begin{tabular}{|c|c|c|c|c|}
\hline Level of importance & Not at all & $\begin{array}{c}\text { To a small } \\
\text { extent }\end{array}$ & $\begin{array}{c}\text { To a } \\
\text { moderate } \\
\text { extent }\end{array}$ & $\begin{array}{c}\text { To a large } \\
\text { extent }\end{array}$ \\
\hline Planner and strategist & 0 & 0 & 5 & 21 \\
\hline Compliance and transaction officer & 0 & 7 & 10 & 9 \\
\hline Growth and innovation catalyst & 0 & 8 & 11 * & 8 * \\
\hline $\begin{array}{l}\text { Corporate governance, citizenship and people } \\
\text { manager }\end{array}$ & 0 & 6 & 9 & 11 \\
\hline
\end{tabular}

\section{Source: $\quad$ SAICA, 2010:23}

* One respondent chose two options

Respondents were then asked to select the one role they believed would be most important to them in three years' time (presented in Table 11) and to indicate the relative importance of each role to them in three years' time (presented in Table 12).

TABLE 11: One role most important to respondents in three years' time

\begin{tabular}{lcc}
\hline & $\begin{array}{c}\text { Number of } \\
\text { respondents }\end{array}$ & $\%$ \\
\hline Planner and strategist & 14 & 54 \\
Compliance and transaction officer & 2 & 7 \\
Growth and innovation catalyst & 9 & 35 \\
Corporate governance, citizenship and people manager & 1 & 4 \\
\hline
\end{tabular}

Source: $\quad$ SAICA, 2010:22

TABLE 12: Relative importance of roles in three years' time

\begin{tabular}{|c|c|c|c|c|}
\hline Level of importance & Not at all & $\begin{array}{c}\text { To a small } \\
\text { extent }\end{array}$ & $\begin{array}{c}\text { To a } \\
\text { moderate } \\
\text { extent }\end{array}$ & $\begin{array}{c}\text { To a large } \\
\text { extent }\end{array}$ \\
\hline Planner and strategist & 0 & 0 & 4 & 22 \\
\hline Compliance and transaction officer & 0 & 9 & 9 & 8 \\
\hline Growth and innovation catalyst & 0 & 6 & 9 & 11 \\
\hline $\begin{array}{l}\text { Corporate governance, citizenship and people } \\
\text { manager }\end{array}$ & 0 & 5 & 9 & 12 \\
\hline
\end{tabular}

Source: SAICA, 2010:22

Overall, results now and looking ahead three years reveal that CFOs feel that their role as planner and strategist is most important to them. This response is in line with results in 2008 (SAICA, 2008). Comparing the relative importance of the roles in 2008 and 2010, at the time of the research and looking forward, results were a lot more mixed, apart from the relative importance of their role as planner and strategist, and will be analysed further .

As much of this part of the research was focused on the model depicted in Table 1, respondents were presented with an open-ended question in which they were asked to provide additional 
comments on their roles and responsibilities. One respondent felt the "role of risk management seems to be under-played in definitions". Given the prominence for CFOs of risk management following the global financial crisis (Deloitte LLP, 2009a; IBM, 2010; KPMG, 2010; Towers Watson, 2008), this valuable comment will be taken into account in future research based on the model. Another, contextualising the roles and responsibilities in the global financial crisis, said: "The global financial crisis brought into sharp relief the key roles of compliance and risk but because our focus had strongly moved in this direction two years prior to the crisis, we have not had to make any significant adjustments to our focus. We continue to make improvements in these areas driven by our business strategy influenced by the crisis but not caused by it." Lastly, one of the respondents gave specific information about the differentiation in roles by stating the following: "The company has clearly defined differentiation in the roles of CEO and CFO/COO, with the former focused on corporate governance, people, reputation and the risk and the latter focused on operational, finance, and growth. The two overlap in strategy, planning, growth and innovation."

\subsection{Views on their current and future time utilisation}

In addressing their four roles, CFOs will spend time on a wide range of responsibilities. One view of the classification of these responsibilities is that presented in Table 1.

In 2008, in order to investigate the time CFOs spent on the responsibilities listed, a number of these were combined, resulting in a list of 21 responsibilities. The list was presented to respondents and they were asked to indicate the relative amount of time they spent on each, based on a five-point Likert scale, with 5 indicating "most of my time" and 1 indicating "no time at all". In 2010, this process was repeated to allow for comparison. By taking the results and calculating the arithmetical mean of grouped discrete data, it is possible to draw comparisons for the results of their time spent now (in 2008 compared to 2010) as well as looking ahead five years in 2008 and three years ahead in 2010. Results are presented in Table 13 and Table 14.

Looking at results for time spent now, as expected, given respondents' view that their role as planner and strategist has become even more important following the global financial crisis (see Table 7) their responsibility for strategic planning, advice and management remained their most important responsibility in 2010 . Turning to responsibilities under the role of compliance and transaction officer, the general decrease in importance of this role to respondents is further evidenced by a decrease in the amount of time respondents felt they spend on each responsibility now, compared to 2008 . For the most part, time spent on responsibilities under the role of corporate governance, citizenship and people manager decreased or remained fairly stable, except for an increase in the time they spend on governance structures. But this finding is in line with expectations given the introduction of the King III code of corporate governance in 2010. Looking at time spent on their role as growth and innovation catalyst, in line with a worldwide trend, respondents are spending more time on seeking opportunities related to mergers and acquisitions (which is the case for strong companies worldwide) and capital provisioning and sourcing. But they are spending less time on new products, markets and business ventures. 
TABLE 13: Comparison of time currently spent on their responsibilities per role

\begin{tabular}{|c|c|c|}
\hline Responsibilities & $\begin{array}{c}2008 \\
\text { Arithmetical mean } \\
\text { of grouped } \\
\text { discrete data }\end{array}$ & $\begin{array}{c}2010 \\
\text { Arithmetical mean } \\
\text { of grouped } \\
\text { discrete data }\end{array}$ \\
\hline \multicolumn{3}{|l|}{ Planner and strategist: } \\
\hline Strategic planning, advice and management & 3.944 & 4.000 \\
\hline Risk identification, assessment and management & 3.389 & 3.462 \\
\hline $\begin{array}{l}\text { Budgeting, pricing, costing, cost and variance analysis and } \\
\text { control }\end{array}$ & 3.056 & 2.692 \\
\hline Performance management and benchmarking & 3.167 & $3.16 \#$ \\
\hline \multicolumn{3}{|l|}{ Compliance and transaction officer: } \\
\hline Transactional processing and financial reporting & 2.722 & 2.500 \\
\hline Management information and forecasting & 3.500 & 3.346 \\
\hline Operationalising finance plans and strategies & 3.263 * & $3.000 \#$ \\
\hline IM and IT maintenance and management & $2.529 \#$ & 2.038 \\
\hline Internal controls, fraud and assurance & 2.778 & 2.423 \\
\hline IFRS implementation and compliance & $2.765 \#$ & $2.360 \#$ \\
\hline Compliance and investor regulations & 2.889 & 2.769 \\
\hline \multicolumn{3}{|l|}{ Corporate governance, citizenship and people's manager: } \\
\hline $\begin{array}{l}\text { Sustainable development, sustainability reporting, triple } \\
\text { bottom line }\end{array}$ & $2.611 \# \star$ & 2.308 \\
\hline Governance structures & 2.889 & 3.154 \\
\hline Attracting and retaining skills, coaching and mentoring & 3.222 & 3.000 \\
\hline Social transformation and Bદદ & 2.833 & 2.423 \\
\hline Investor, stakeholder and market liaison and communication & $3.563 \dagger$ & 3.423 \\
\hline Ethics and values & $2.722 \#$ * & 2.692 \\
\hline $\begin{array}{l}\text { Liaison with the board, audit committee, internal audit and } \\
\text { external audit }\end{array}$ & 3.778 & 3.808 \\
\hline \multicolumn{3}{|l|}{ Growth and innovation catalyst: } \\
\hline Mergers and acquisitions & $2.941 \#$ & 3.269 \\
\hline Capital provision and sourcing & 3.278 & 3.385 \\
\hline New products, markets and business ventures & 2.444 & 2.231 \\
\hline
\end{tabular}

\section{Source: Voogt, 2010; author's own calculations}

* $\quad$ One respondent chose two options

\# One respondent did not choose an option

$\dagger \quad$ Two respondents did not choose an option

A comparison of respondents' expectations as to how they would spend their time in the future in 2008 and 2010 reveals a shift in perceptions (see Table 14). 
TABLE 14: Comparison of time spent on their responsibilities per role in the future

\begin{tabular}{|c|c|c|}
\hline Responsibilities & $\begin{array}{c}2008 \text { - Looking } \\
\text { ahead five years } \\
\text { Arithmetical mean } \\
\text { of grouped } \\
\text { discrete data }\end{array}$ & $\begin{array}{c}2010 \text { - Looking } \\
\text { ahead three years } \\
\text { Arithmetical mean } \\
\text { of grouped } \\
\text { discrete data }\end{array}$ \\
\hline \multicolumn{3}{|l|}{ Planner and strategist: } \\
\hline Strategic planning, advice and management & 4.333 & 4.077 \\
\hline Risk identification, assessment and management & $3.105 *$ & 3.654 \\
\hline $\begin{array}{l}\text { Budgeting, pricing, costing, cost and variance analysis and } \\
\text { control }\end{array}$ & 2.842 * & $2.680 \#$ \\
\hline Performance management and benchmarking & 3.667 & 3.269 \\
\hline \multicolumn{3}{|l|}{ Compliance and transaction officer: } \\
\hline Transactional processing and financial reporting & 2.211 * & 3.154 \\
\hline Management information and forecasting & $3.412 \#$ & 3.346 \\
\hline Operationalising finance plans and strategies & $3.313 \dagger$ & $3.200 \#$ \\
\hline IM and IT maintenance and management & 2.500 & 2.259 * \\
\hline Internal controls, fraud and assurance & 2.667 & 2.423 \\
\hline IFRS implementation and compliance & 2.556 & 2.269 \\
\hline Compliance and investor regulations & 3.000 & 2.885 \\
\hline \multicolumn{3}{|l|}{ Corporate governance, citizenship and people's manager: } \\
\hline $\begin{array}{l}\text { Sustainable development, sustainability reporting, triple } \\
\text { bottom line }\end{array}$ & 3.167 & 2.615 \\
\hline Governance structures & 2.944 & 2.654 \\
\hline Attracting and retaining skills, coaching and mentoring & 3.722 & 3.231 \\
\hline Social transformation and BદE & 2.944 & 2.692 \\
\hline Investor, stakeholder and market liaison and communication & 3.778 & 3.577 \\
\hline Ethics and values & $2.941 \#$ & $2.720 \#$ \\
\hline $\begin{array}{l}\text { Liaison with the board, audit committee, internal audit and } \\
\text { external audit }\end{array}$ & 3.778 & 3.769 \\
\hline \multicolumn{3}{|l|}{ Growth and innovation catalyst: } \\
\hline Mergers and acquisitions & 3.316 * & 3.500 \\
\hline Capital provision and sourcing & 3.500 & 3.538 \\
\hline New products, markets and business ventures & $3.294 \#$ & 2.538 \\
\hline
\end{tabular}

\section{Source: Voogt, 2010; author's own calculations}

\footnotetext{
* One respondent chose two options

\# One respondent did not choose an option

$\dagger \quad$ Two respondents did not choose an option
}

Results related to their views of time spent on their responsibilities in the future (as presented in Table 14) reveal a decrease in time expected to be spent in 2010 for all the responsibilities under their role as planner and strategist and corporate governance, citizenship and people manager, except for that of risk identification, assessment and management. Under their role as compliance and transaction officer, time expected to be spent on all categories is expected to decrease, except for a dramatic rise in time expected to be spent on transactional processing 
and financial reporting. This finding is not in line with the global trend over the past decade that CFOs spend less time on their traditional role as scorekeeper (IBM Business Consulting Services, 2003; ICAA, 2007; Myers, 2002; Voogt, 2010). Lastly, as regards their role as growth and innovation catalyst, respondents expected to spend more time looking for opportunities in mergers and acquisitions and a little more time on capital provisioning and sourcing.

\section{ANALYSIS OF FINDINGS}

This research has revealed a number of significant findings related to the effects of the global financial crisis on the CFOs of the largest listed companies on the JSE Ltd as well as significant findings around their most important roles and responsibilities.

As to the effects of the global financial crisis on CFOs, around two-thirds of respondents felt that their roles and responsibilities had changed due to the global financial crisis. This finding is possibly in line with expectations, seeing that South Africa did not suffer the same consequences of the global financial crisis that other countries did, particularly in Europe, even though many of the targeted companies are multinational organisations. But, looking ahead three years, only $65 \%$ of respondents felt their role as CFO would change, compared to $94 \%$ of respondents who felt that way in 2008 looking ahead five years (SAICA, 2008). Therefore, many more of the CFOs of the largest listed companies on the JSE Ltd expect more stability in their role than before, perhaps pointing to a period of consolidation in the shorter term.

Concerning the role that is most important to CFOs now and looking forward, as well as the relative importance of the roles to them, results revealed that their role as planner and strategist was still most important to them. However, a comparison between the responses of 2008 and 2010 on the one role most important to them as well as on the relative importance of the roles (based on arithmetical mean of grouped discrete data) reveals significant findings (see Table 15 and Table 16).

Focusing on the comparison in Table 15, the third significant finding from this study looking at respondents' views on their one most important role now and in the future is that their role as planner and strategist remains most important now by far, in line with results in 2008.

Furthermore, when selecting one role most important to them in the future, results in 2010 have remained in line with those of 2008 , in that their roles as planner and strategist and growth and innovation catalyst remain very important. As in 2008, the perception that the remaining two roles were not their most important roles remains.

While results for their one most important role have remained fairly stable, the same cannot be said for their ranking of the four roles based on the relative importance of each. Therefore, the fourth significant finding of this study is that there has been a shift in perceptions as to the relative importance to respondents of their four roles now and looking ahead five years when compared to their views in 2008. Even though their role as planner and strategist remains most important to them, the relative importance of their role as corporate governance, citizenship and people manager has increased significantly both now and looking forward (see Table 16). 
TABLE 15: Comparison of one role most important now and in the future

\begin{tabular}{|c|c|c|c|}
\hline \multicolumn{2}{|c|}{$\begin{array}{l}2008 \\
\begin{array}{l}\text { Ranking based on the one role most important to } \\
\text { respondents }\end{array}\end{array}$} & \multicolumn{2}{|c|}{$\begin{array}{l}2010 \\
\begin{array}{l}\text { Ranking based on the one role most important to } \\
\text { respondents }\end{array}\end{array}$} \\
\hline Now & In five years' time & Now & In three years' time \\
\hline $\begin{array}{l}\text { 1. Planner and } \\
\text { strategist }(66 \%)\end{array}$ & $\begin{array}{l}\text { 1. Planner and } \\
\text { strategist }(72 \%)\end{array}$ & $\begin{array}{l}\text { 1. Planner and } \\
\text { strategist }(70 \%)\end{array}$ & $\begin{array}{l}\text { 1. Planner and } \\
\text { strategist }(54 \%)\end{array}$ \\
\hline $\begin{array}{l}\text { 2. Compliance and } \\
\text { transaction officer } \\
(22 \%)\end{array}$ & $\begin{array}{l}\text { 2. Growth and } \\
\text { innovation catalyst } \\
(22 \%)\end{array}$ & $\begin{array}{l}\text { 2. Compliance and } \\
\text { transaction officer } \\
(15 \%)\end{array}$ & $\begin{array}{l}\text { 2. Growth and } \\
\text { innovation catalyst } \\
(35 \%)\end{array}$ \\
\hline $\begin{array}{l}\text { 3. Corporate } \\
\text { governance, } \\
\text { citizenship and } \\
\text { people manager }(6 \%) \\
\text { AND } \\
\text { Growth and } \\
\text { innovation catalyst } \\
(6 \%)\end{array}$ & $\begin{array}{l}\text { 3. Compliance and } \\
\text { transaction officer } \\
(6 \%) \\
\text { 4. Corporate } \\
\text { governance, } \\
\text { citizenship and } \\
\text { people manager }(0 \%)\end{array}$ & $\begin{array}{l}\text { 3. Corporate } \\
\text { governance, } \\
\text { citizenship and } \\
\text { people manager } \\
(7.5 \%) \\
\text { AND } \\
\text { Growth and } \\
\text { innovation catalyst } \\
(7.5 \%)\end{array}$ & $\begin{array}{l}\text { 3. Compliance and } \\
\text { transaction officer } \\
(7 \%) \\
\text { 4. Corporate } \\
\text { governance, } \\
\text { citizenship and } \\
\text { people manager }(4 \%)\end{array}$ \\
\hline
\end{tabular}

Source: SAICA, 2010:22; SAICA, 2008:15

TABLE 16: Comparison of the relative importance of roles now and in the future

\begin{tabular}{|c|c|c|c|}
\hline \multicolumn{2}{|c|}{$\begin{array}{c}2008 \\
\begin{array}{c}\text { Ranking based on the relative importance of the } \\
\text { four roles }\end{array}\end{array}$} & \multicolumn{2}{|c|}{$\begin{array}{l}2010 \\
\begin{array}{c}\text { Ranking based on the relative importance of the } \\
\text { four roles }\end{array}\end{array}$} \\
\hline Now & In five years' time & Now & In three years' time \\
\hline $\begin{array}{l}\text { 1. Planner and } \\
\text { strategist (3.778) }\end{array}$ & $\begin{array}{l}\text { 1. Planner and } \\
\text { strategist }(3.889)\end{array}$ & $\begin{array}{l}\text { 1. Planner and } \\
\text { strategist }(3.808)\end{array}$ & $\begin{array}{l}\text { 1. Planner and } \\
\text { strategist }(3.846)\end{array}$ \\
\hline $\begin{array}{l}\text { 2. Compliance and } \\
\text { transaction officer } \\
(3.722)\end{array}$ & $\begin{array}{l}\text { 2. Growth and } \\
\text { innovation catalyst } \\
(3.722)\end{array}$ & $\begin{array}{l}\text { 2. Corporate } \\
\text { governance, } \\
\text { citizenship and } \\
\text { people manager } \\
(3.538)\end{array}$ & $\begin{array}{l}\text { 2. Corporate } \\
\text { governance, } \\
\text { citizenship and } \\
\text { people manager } \\
(3.615)\end{array}$ \\
\hline $\begin{array}{l}\text { 3. Corporate } \\
\text { governance, } \\
\text { citizenship and } \\
\text { people manager } \\
(3.444)\end{array}$ & $\begin{array}{l}\text { 3. Corporate } \\
\text { governance, } \\
\text { citizenship and } \\
\text { people manager } \\
(3.471)\end{array}$ & $\begin{array}{l}\text { 3. Compliance and } \\
\text { transaction officer } \\
(3.077)\end{array}$ & $\begin{array}{l}\text { 3. Growth and } \\
\text { innovation catalyst } \\
(3.538)\end{array}$ \\
\hline $\begin{array}{l}\text { 4. Growth and } \\
\text { innovation catalyst } \\
(3.167)\end{array}$ & $\begin{array}{l}\text { 4. Compliance and } \\
\text { transaction officer } \\
(3.333)\end{array}$ & $\begin{array}{l}\text { 4. Growth and innovation } \\
\text { catalyst }(3.000)\end{array}$ & $\begin{array}{l}\text { 4. Compliance and } \\
\text { transaction officer } \\
(3.308)\end{array}$ \\
\hline
\end{tabular}

Source: Author's own calculations

When one considers respondents' views in 2008 and 2010 on the extent to which they spend time on responsibilities in their role as corporate governance, citizenship and people manager now and in the future, in light of their perception of an increase in the relative importance of that role, there is a clear discrepancy. Looking at the time they spend on responsibilities in that role 
now, as compared to results in 2008, there is a decrease in all the responsibilities listed, except for that spent on governance structures. There is also a small increase in time spent on liaison with the board, audit committee, external audit and internal audit. Looking at their expected time spend in the future on these responsibilities in 2010 compared to 2008, they expect to spend less time on all of their responsibilities. The difference in their views on the relative importance of their role as corporate governance, citizenship and people manager as opposed to the time they spend and expect to spend on their responsibilities under this role warrants further investigation.

Turning to the time they spend on their responsibilities under the four roles now, there are a number of significant findings. Firstly, the 2008 research highlighted that compared to international trends, CFOs in the South African context spend little time on information management and IT maintenance and management (Voogt, 2010). Even though the King III code on corporate governance has introduced the concept of IT governance (Institute of Directors, 2009) and CFOs would have to play their part therein, results in 2010 reveal that CFOs are spending even less time on this responsibility than in 2008. The reasons for this warrant further investigation. On the positive side, the time they spend on governance structures has increased. Secondly, given the global prominence of sustainable development, sustainability reporting and the triple bottom line, results in 2008 were somewhat surprising in indicating that CFOs at the largest listed companies spent little time on this issue (Voogt, 2010). This matter also warrants further investigation.

In response to the 2008 results related to the relatively little time that the CFOs of the largest listed companies in South Africa spend on IT matters and sustainability, the research conducted in 2010 included a number of questions on this subject. Firstly, when asked whether they thought they should be responsible for IT governance, 25 respondents gave their views. Of these, 12 (48\%) felt that it was their responsibility, while $13(52 \%)$ felt that it was not part of their responsibilities. As to whether they thought they should be responsible for IT systems and controls, six (24\%) answered in the affirmative, while 19 (76\%) disagreed. Secondly, in order to probe the extent to which CFOs are involved in various aspects of sustainability, they were asked to indicate their involvement in four tasks presented in Table 17.

TABLE 17: Extent of involvement in tasks related to sustainability

\begin{tabular}{|c|c|c|c|c|}
\hline & Not at all & $\begin{array}{c}\text { To a } \\
\text { limited } \\
\text { extent }\end{array}$ & $\begin{array}{c}\text { To a } \\
\text { moderate } \\
\text { extent }\end{array}$ & $\begin{array}{l}\text { To a large } \\
\text { extent }\end{array}$ \\
\hline $\begin{array}{l}\text { Planning (including the financial aspects, e.g. } \\
\text { budgeting and benefit analysis) }\end{array}$ & 2 & 13 & 11 & 0 \\
\hline Execution & 9 & 14 & 2 & 1 \\
\hline Reporting & 4 & 16 & 5 & 1 \\
\hline $\begin{array}{l}\text { Incorporating sustainability in the broader } \\
\text { organisational strategy }\end{array}$ & 2 & 15 & 9 & 0 \\
\hline
\end{tabular}

Source: SAICA, 2010:4

As regards respondents' expected future time spend, the most significant finding (which has also been highlighted above) is the sharp increase in their expected time spend on transactional processing and financial reporting, which is another matter than warrants further research, given the trend that $\mathrm{CFO}$ s spend less time on this traditional role globally. In addition, given the 
results related to information management and IT maintenance and management, as well as sustainable development, sustainability reporting and the triple bottom line, it must be noted that respondents expect to spend even less time on these two responsibilities going forward.

\section{CONCLUSION AND AREAS FOR FURTHER RESEARCH}

This article presented the views of the CFOs of the 40 largest listed companies in South Africa on the extent of the changes to their roles and responsibilities following the global financial crisis.

Prior to the global financial crisis, research revealed that the role of CFOs had changed from that of scorekeepers to that of strategists and business partners. The global financial crisis added yet more dimensions to this debate and presented a case for CFOs to focus even more on strategy. The results of the literature review presented in this article revealed that, globally, CFOs were also found to be more risk averse following the global financial crisis. They were more focused on cash and the availability of credit, as well as on merger and acquisition activities in strong companies in order to harness new opportunities. But research also revealed that there was even more pressure on the skills set they require, and many CFOs felt that there were more volatile times ahead.

This research, which achieved a high response rate of $65 \%$ through the application of a questionnaire in a census, revealed a number of significant findings. These were:

1. Around two-thirds of respondents felt their roles changed due to the global financial crisis.

2. In 2010 , only $65 \%$ of respondents felt their roles would change going forward, as opposed to $94 \%$ who felt that way in 2008 .

3. As in 2008, the CFOs of the largest listed companies felt their most important role now and looking ahead was that of planner and strategist.

4. A comparison of the ranking of the four roles looking ahead, based on the relative importance of each role, shows a distinct shift in perceptions in 2010 from the position in 2008 , towards that of corporate governance, citizenship and people manager as the second most important role.

5. Even though respondents' perceptions were that their role as corporate governance, citizenship and people manager was becoming more important, this is not borne out by the decrease in time they presently spend (and expect in the future to spend) on these responsibilities when comparing 2010 and 2008.

6. Even though international trends have revealed a need for CFOs to become more involved in IT matters, this research has revealed that the CFOs of the largest listed companies on the JSE Ltd spend, and expect in the future to spend, even less time on information management and IT maintenance and management in 2010 than was the case in 2008.

7. Similarly, they spend and expect to spend even less time on sustainable development, sustainability reporting and the triple bottom line.

8. Turning to respondents' view on the time they expect to spend on their responsibilities in the future, there was a marked increase in the amount of time they thought they would spend on transactional processing and financial reporting, which goes against trends internationally. 
A number of specific areas for further research were also identified. Firstly, thought must be given to whether the model depicted in Table 1 focuses sufficiently on risk management. Secondly, the discrepancy between respondents' view that their role as corporate governance, citizenship and people manager has become more important, while they spend and expect to spend less time on responsibilities in this capacity, warrants further research. Thirdly, CFOs surveyed are spending less time on IT and sustainability matters than in 2008. Given the importance of both these responsibilities, the reasons behind these findings should be probed. Lastly, the reasons why respondents feel they will spend more time on transactional processing and financial reporting going forward should be investigated, as this is not in line with trends internationally.

Furthermore, as this research focused on the views of the CFOs of the largest listed companies, areas for future research would be to apply the questionnaire to other listed and private companies and to the arena of the public sector in order to gain further country-specific insights into the effects of the global financial crisis.

\section{LIST OF REFERENCES}

A.E. Feldman Blog. (2008). CFO Skills set evolving amid financial crisis. [0n-line] Available: http://blog.aefeldman.com/2008/10/23/cfo-skill-set-evolving-amid-financial-crisis/. (Accessed 3 June 2010).

Ali, S. (2009). International Economic Bulletin. April 2009. [On-line] Available:

http://www.carnegieendowement.org/publications/index.cfm?fa=view\&id=22995. (Accessed 28 June 2010).

Arieff, A., Weiss, M.A. \& Jones, V.C. (2010). The global economic crisis: Impact on sub-Saharan Africa and g/obal policy responses. CRS Report for Congress. Congressional Research Services. [0n-line] Available: http://www.fas.org/sgp/crs/row/R40778.pdf. (Accessed 28 June 2010).

Aronson, B.E. (2010). The financial crisis one year later: proceedings of a panel discussion on lessons of the financial crisis and implications for regulatory reform. Creighton Law Review, 43(2), pp. 275322.

Banham, R. (2009). The standoff continues, CFO Magazine, 1 March 2009. [On-line] Available: http://www.cfo.com/printable/article.cfm/13174293. (Accessed 13 March 2009).

Bragg, S.M. (2007). The new CFO financial leadership manual. Englewood Cliffs, NJ: Wiley.

Bruggemans, C. (2007/2008). Grootste bankkrisis gaan ons verby, ASA Accountancy SA, December 2007/January 2009:47.

Censky, A. (9 June 2010). Double dip recession: What are the odds? [0n-line] Available: http://money.cnn.com/2010/06/09/news/economy/double_dip_recession/index.htm. (Accessed 3 July 2010).

CF0 Publishing Corp. (2009). Road to recovery: Finance's views on IT investments for efficiency and competitive advantage. [0n-line] Available:

http://www.cfo.com/whitepapers/index.cfm/displaywhitepapers/14441738. (Accessed 15 June 2010).

CPA Australia. (2009). Top tips for CFOs. [On-line] Available:

http://gfc.cpaaustralia.com.au/toolkit/top-tips-for-cfos/. (Accessed 28 June 2010). 
Deloite. (2008). Panic, turmoil and rescues: now what? A CFO perspective from Deloitte.

Deloitte Development LLC. 2007. Finance transformation: building a risk intelligent finance function. [On-line] Available:

http://www.deloitte.com/dtt/cda/doc/content/Financial\%20transformation(2).pdf. (Accessed 14 April 2007).

Deloitte LLP. (2009a). The Deloitte CFO Survey Priorities for 2009: Cash, confidence, costs. [0n-line] Available: https://www2.deloitte.com/assets/Dcom-

UnitedKingdom/Local\%20Assets/Documents/UK_DR_CF0_Survey_P4_2008_v2.pdf. (Accessed 12 June 2010).

Deloitte LLP. (2009b). The Deloitte CFO Survey Amid the gloom, glimmers of hope. [0n-line] Available: http://www.deloitte.com/assets/DcomUnitedKingdom/Local\%20Assets/Documents/UK_DR_CFO_Survey_P1_2009.pdf. (Accessed 15 June 2010).

Ernst \& Young. (2008). What's next for the CFO? Where ambition meets reality. EYGM Limited.

Financial Executives International. (2005). The role of the CFO today and beyond. FEI Canada Research Studies. Toronto: Financial Executives International Canada.

Financial Times. (2008). The CFO in Uncertain Times. In association with IBM. [0n-line] Available: http://www.ftconferences.com/userfiles/files/CF0\%20In\%20Uncertain\%20Times\%20Summary\%20Re port\%20April\%2008.pdf. (Accessed 20 May 2010).

Germain, R. (2009). Financial order and world politics: crisis, change and continuity. International Affairs, 85(4), pp. 669-687.

IBM. (2010). The New Value Integrator Insights from the IBM Global Chief Financial Officer Study. [0nline] Available: http://www-935.ibm.com/services/us/cfo/cfostudy2010/. (Accessed 17 May 2010).

IBM Business Consulting Services. (2003). An IBM Institute for Business Value executive brief. CFO Survey: current state and future direction. [On-line] Available: http://www-

935.ibm.com/services/in/index.wss/ibvstudy/igs/x1022302?cntxt=x1021855. (Accessed 14 April 2007).

Institute of Chartered Accountants in Australia (ICAA). (1998). CFO of the future. [0n-line] Available: http://www.Imnconsulting.com.au/CFOoftheFuture2.pdf. (Accessed 7 July 2007).

Institute of Chartered Accountants in Australia (ICAA). (2007). CFO of the future: the evolving role of the CFO. Joint research project between KPMG Australia and the Institute of Chartered Accountants in Australia. [0n-line] Available:

http://www.charteredaccountants.com.au/files/documents/institute_survey_cfos.pdf. (Accessed 7 June 2008).

Institute of Directors. 2009. King Report on Governance for South Africa. Institute of Directors in Southern Africa. Electronic version.

International Federation of Accountants (IFAC). (2002). The role of the chief financial officer in 2010. Booklet prepared by the Financial Management Accounting Committee. New York: International Federation of Accountants.

International Monetary Fund (IMF). (2009). Impact of the global financial crisis on Sub-Saharan Africa. [On-line] Available:

http://www.imf.org/external/pubs/ft/books/2009/afrglobfin/ssaglobalfin.pdf. (Accessed 28 June 2010). 
Kana, S. (2009). Understanding the financial impact of the current Global Financial Crisis on Business, ASA Accountancy SA, October 2009:20-22.

Korn/Ferry Institute. (2010). Perspectives of a CFO masterclass. [On-line] Available: http://www.kornferryinstitute.com/files/pdfl/KF_CFO_Perspectives_2010_low.pdf. (Accessed 28 June 2010).

KPMG. (2010). The CFO's evolving strategic role. [0n-line] Available:

http://www.kpmg.com/Global/en/IssuesAndInsights/ArticlesPublications/Pages/The-CFOs. (Accessed 22 April 2010).

Legg, M. \& Harris, J. (2009). How the American dream became a global nightmare: an analysis of the causes of the global financial crisis. University of New South Wales Law Journal, 32(2), pp. 350-389.

Macias, J.B. \& Massa, I. (2009). The global financial crisis and sub-Saharan Africa The effects of slowing private capital inflows on growth. Working paper 304. Overseas Development Institute. [0nline] Available: http://www.odi.org.uk/resources/download/3367.pdf. (Accessed 27 June 2010).

Myers, R. (2002). How CFOs stretch boundaries. Journal of Accountancy, 193(5), pp. 75-81.

0 'Driscoll, G.P. (2009). The financial crisis: origins and consequences. Intercollegiate Review, 44(2), pp. 4-12.

Overseas Development Institute (ODI). (2008). Effects of the global financial crisis on developing countries and emerging markets. Policy responses to the crisis. [On-line] Available: http://www.odi.org.uk/resources/download/2613.pdf. (Accessed 28 June 2010).

Overseas Development Institute (ODI). (2009). The global financial crisis and developing countries. [On-line] Available: http://www.odi.org.uk.fs/resources/fs/download/fs/3251.pdf. (Accessed 28 June 2010).

Paton, C. (2 July 2010). Different world ahead, Financial Mail, 38-39.

Roubini, N. (11 March 2010). Beware of double dip recession. Forbes.com. [On-line] Available: http://www.forbes.com/2010/03/10/united-states-recovery-recession-opinions-columnistsnouriel-roubini.html. (Accessed 3 July 2010).

Shiller, R.J. (14 May 2010). Fear of double dip recession could cause one, New York Times (electronic version). [On-line] Available: http://www.nytimes.com/2010/05/16/business/16view.html?_r=1. (Accessed 3 July 2010).

South African Government Information. (2009a). Framework for South Africa's response to the international economic crisis. [On-line] Available:

http://www.info.gov.za/view/DownloadFileAction?id=96381. (Accessed 27 May 2010).

South African Government Information. (2009b). South Africa's response to the international economic crisis. [0n-line] Available: http://www.info.gov.za/issues/economic_crisis/index.html. (Accessed 27 May 2010).

South African Institute of Chartered Accountants (SAICA). (2008). The South African CFO of the future. SAICA: Johannesburg.

South African Institute of Chartered Accountants (SAICA). (2009). SA's chartered accountants dominate boards of JSE's top 200. [On-line] Available:

http://www.saica.co.za/tabid/695/itemid/1877/SAs-chartered-accountants-dominate-boards-ofJSE.aspx. (Accessed 9 0ctober 2009). 
South African Institute of Chartered Accountants (SAICA). (2010). The CFO of the Future: The Effects of the Global Financial Crisis. Johannesburg: SAICA.

South African Reserve Bank. (2010). Financial Stability Review March 2010. [0n-line] Available: http://www.reservebank.co.za/internet/Publication.nsf/LADV/69AA9021607E063B422577130047AB2 F/\$File/FSR+March+2010+with+bookmarks.pdf. (Accessed 10 June 2010).

Te Velde, D.W. (2008). The global financial crisis and developing countries. Overseas Development Institute. [On-line] Available: http://www.odi.org.uk/resources/download/2462.pdf. (Accessed 10 June 2010).

Towers Watson. (2008). Financial crisis intensifies interest in risk management among CFOs. [0nline] Available:

http://www.towersperrin.com/tp/showdctmdoc.jsp?url=Master_Brand_2/USA/News/Spotlights/2008 /Sept/2008_09_30_spotlight_cfo_survey.htm. (Accessed 3 June 2010).

Voogt, T.L. (2010). An exploratory study of the focus areas of South African Top 40 company CF0s. Meditari, 18(1), pp. 76-92.

Zuma, J.Z. (2010). State of the nation address. 2010. [0n-line] Available:

http://www.info.gov.za/speeches/2010/1002111905.htm. (Accessed 8 June 2010). 